\title{
Characterization and Genome Analysis of Staphylococcus aureus Podovirus CSA13 and Its Anti-Biofilm Capacity
}

\author{
Yoyeon Cha ${ }^{1,2,+}$, Jihwan Chun ${ }^{1,2,3,+} \mathbb{D}$, Bokyung Son ${ }^{1,2,4}$ and Sangryeol Ryu $1,2,3,4, *(\mathbb{D}$ \\ 1 Department of Food and Animal Biotechnology, Seoul National University, Seoul 08826, Korea; \\ dianacha2006@naver.com (Y.C.); jihwanchun@gmail.com (J.C.); sonbk0722@gmail.com (B.S.) \\ 2 Department of Agricultural Biotechnology, Seoul National University, Seoul 08826, Korea \\ 3 Research Institute of Agriculture and Life Sciences, Seoul National University, Seoul 08826, Korea \\ 4 Center for Food and Bioconvergence, Seoul National University, Seoul 08826, Korea \\ * Correspondence: sangryu@snu.ac.kr; Tel.: +82-2-880-4863; Fax: +82-2-873-5095 \\ + These authors contributed equally to this work.
}

Received: 25 November 2018; Accepted: 10 January 2019; Published: 12 January 2019

check for updates

\begin{abstract}
Staphylococcus aureus is one of the notable human pathogens that can be easily encountered in both dietary and clinical surroundings. Among various countermeasures, bacteriophage therapy is recognized as an alternative method for resolving the issue of antibiotic resistance. In the current study, bacteriophage CSA13 was isolated from a chicken, and subsequently, its morphology, physiology, and genomics were characterized. This Podoviridae phage displayed an extended host inhibition effect of up to $23 \mathrm{~h}$ of persistence. Its broad host spectrum included methicillin susceptible S. aureus (MSSA), methicillin resistant $S$. aureus (MRSA), local S. aureus isolates, as well as non-aureus staphylococci strains. Moreover, phage CSA13 could successfully remove over $78 \%$ and $93 \%$ of MSSA and MRSA biofilms in an experimental setting, respectively. Genomic analysis revealed a 17,034 bp chromosome containing 18 predicted open reading frames (ORFs) without $t$ RNAs, representing a typical chromosomal structure of the staphylococcal Podoviridae family. The results presented here suggest that phage CSA13 can be applicable as an effective biocontrol agent against $S$. aureus.
\end{abstract}

Keywords: bacteriophage; Staphylococcus aureus; anti-biofilm; genome analysis

\section{Introduction}

Staphylococcus aureus possesses a diverse array of armaments that contribute to life-threatening infections, such as skin abscesses, endocarditis, pneumonia, and toxic shock syndrome [1]. Its ability to form biofilm on biotic and abiotic surfaces is one of the main hurdles for the eradication of $S$. aureus in both clinical and food environments [2,3]. Moreover, the emergence of antibiotic-resistant isolates in clinical environments poses a serious threat to global human health.

To cope with such problems, bacteriophages (phages) have been considered as alternative antimicrobial agents for treating multidrug-resistant bacteria and biofilm-associated infections $[4,5]$. Virulent phages have been considered to be promising as potential therapeutic agents, as they are safe, highly specific, and capable of lysing and killing infected target bacterial cells [6,7]. Furthermore, some phages produce enzymes with polysaccharide depolymerase activity, which can degrade capsular polysaccharides and exopolysaccharides (EPS), such as polysaccharide intercellular adhesin (PIA), a major structural component of most biofilms [5,8-10]. Recently, genetic engineering endowed phages with enhanced abilities for biofilm disposal, such as expressing stronger hydrolases or interfering quorum sensing [11]. 
Taxonomically, the majority of S. aureus phages are double-stranded DNA phages belonging to the Siphoviridae family, and a smaller number of them belong to the Podoviridae and Myoviridae families, which are primarily virulent phages [12]. Each family can be distinguished based on genome size and morphology: Podoviridae ( $<20 \mathrm{~kb})$, short and non-contractile tail; Siphoviridae $(\approx 40 \mathrm{~kb})$, icosahedral head, long, non-contractile, flexible, and thin tail; Myoviridae ( $>125 \mathrm{~kb})$, icosahedral head, long, contractile, rigid, and thick tail [12]. Due to their strict diversity, the S. aureus phages of each family retain characteristic genome structures, and hence, an orthologous genetic element does not necessarily appear across all the families [12]. The absence of universal genes in phage genomes has resulted in the development of alternative approaches, such as those based on structural genes, phage proteome, or phage orthologous groups (POGs), to unveil the biodiversity of these phages [13,14].

In this study, a new staphylococcal phage, CSA13, was isolated from a chicken, and its characteristics in terms of physiology, genomics, and bioinformatics were investigated. Specifically, phage CSA13 exhibited outstanding anti-biofilm activity against both methicillin-resistant $S$. aureus (MRSA) and methicillin-susceptible S. aureus (MSSA). As far as we know, this is the first report describing the use of a Podoviridae phage as an anti-biofilm agent. Taking into account its broad host range, along with its anti-biofilm activity, phage CSA13 could be developed as a promising biocontrol agent in both clinical and food industry settings.

\section{Materials and Methods}

\subsection{Bacteriophage Isolation and Propagation}

Bacteriophage CSA13 was isolated from chickens by using the $S$. aureus clinical isolate strain FMB-1 as a bacterial host. Whole chicken meat was homogenized for $1 \mathrm{~min}$ with $1 \mathrm{~L}$ of Bolton broth, supplemented with the Bolton Broth Selective Supplement (10 mg Cefoperazone, $10 \mathrm{mg}$ Trimethoprim, $10 \mathrm{mg}$ Vancomycin, and $25 \mathrm{mg}$ Cycloheximide). The sample was then incubated at $42{ }^{\circ} \mathrm{C}$ for $12 \mathrm{~h}$ in micro-aerobic conditions $\left(6 \% \mathrm{O}_{2}, 10 \% \mathrm{CO}_{2}, 84 \% \mathrm{~N}_{2}\right)$. After incubation, the broth was centrifuged at $10,000 \times g$ for $5 \mathrm{~min}$ and filtered to remove bacterial cells. Following centrifugation and filtration, $5 \mathrm{~mL}$ of the filtrate was mixed with $5 \mathrm{~mL}$ of $2 \times$ Tryptic soy broth (TSB) and sub-cultured with the host strain at $37^{\circ} \mathrm{C}$, with shaking at $220 \mathrm{rpm}$ for $12 \mathrm{~h}$. After incubation, the culture was centrifuged at $10,000 \times g$ for $10 \mathrm{~min}$ and filtered to exclude any bacterial cells. The presence of phage in the filtrate was confirmed by spotting $10 \mu \mathrm{L}$ of ten-fold, serial-diluted filtrates on soft agar (TSB containing $0.4 \%$ agar) containing $100 \mu \mathrm{L}$ of host $S$. aureus culture. The plates were incubated overnight at $37^{\circ} \mathrm{C}$, and formation of plaques was monitored. Single plaques were picked with a sterile tip and eluted in sodium chloride-magnesium sulfate (SM) buffer ( $50 \mathrm{mM}$ Tris- $\mathrm{HCl}$, $\left.\mathrm{pH} 7.5,100 \mathrm{mM} \mathrm{NaCl}, 8 \mathrm{mM} \mathrm{MgSO}_{4} \cdot 7 \mathrm{H}_{2} \mathrm{O}\right)$. This purification step was repeated more than three times. For propagation of the phage, TSB was first inoculated with the host $\mathrm{S}$. aureus strain and incubated at $37^{\circ} \mathrm{C}$, with shaking at $220 \mathrm{rpm}$ for $1.5 \mathrm{~h}$. Subsequently, the phage was added at a multiplicity of infection (MOI) of 1 , followed by a $3 \mathrm{~h}$ incubation in the same conditions. To prepare the phage at a high titer, the propagated phages were precipitated with polyethylene glycol (PEG) 6000 and concentrated by ultracentrifugation using a $\mathrm{CsCl}$ density gradient [15].

\subsection{Transmission Electron Microscopy (TEM) Analysis}

Staphylococcus phage CSA13 was analyzed using transmission electron microscopy (TEM). The phage suspension was placed on a carbon-coated copper grid and negatively stained with $2 \%$ uranyl-acetate $(\mathrm{pH} 4.0)$. The sample was examined under an energy-filtering transmission electron microscope at an operating voltage of $120 \mathrm{kV}$ [16]. Phage CSA13 was identified and classified according to the guidelines of the International Committee on Taxonomy of Viruses.

\subsection{Determination of the Bacteriophage Antimicrobial Spectrum}

The bacterial strains listed in Table 1 were incubated overnight at $37^{\circ} \mathrm{C}$. A hundred microliters of each bacterial culture was mixed with $5 \mathrm{~mL}$ of soft agar (TSB containing $0.4 \%$ agar) and overlaid on 
tryptic soy agar (TSA) plates. Subsequently, $10 \mu \mathrm{L}$ of serially diluted phage CSA13 lysates (ten-fold, $10^{12}$ to $10^{5}$ plaque forming unit (PFU)/mL) were spotted onto the prepared plates and incubated at $37^{\circ} \mathrm{C}$ for at least $6 \mathrm{~h}$ in order to obtain single plaques. After incubation, the infectivity could be determined based on the appearance of the spots: " $\mathrm{C}$ ", clear single plaques; " $\mathrm{T}$ ", turbid single plaques; "I", inhibited growth without single plaques;"-", no lysis nor growth inhibition.

\subsection{Bacterial Inhibition Assay}

$50 \mathrm{~mL}$ of TSB was inoculated with the host $S$. aureus strain and incubated at $37^{\circ} \mathrm{C}$ until the early exponential growth phase $\left(2.6 \times 10^{8} \pm 0.2 \times 10^{8} \mathrm{CFU} / \mathrm{mL}\right)$. The culture was then infected with the phage at an MOI of 1 . The $\mathrm{OD}_{600}$ was measured each hour after phage infection for $23 \mathrm{~h}$, with no measurements being taken between the 14th and 22nd hours [17]. An un-infected culture was used as a control. All the experiments were performed in triplicate.

\subsection{One-Step Growth Curve Assay}

A one-step growth curve analysis was performed as described previously [18]. Briefly, phage was mixed with the $S$. aureus host strain in the early exponential growth phase at an MOI of 0.001 . After incubation at $25{ }^{\circ} \mathrm{C}$ for $10 \mathrm{~min}$ to allow for adsorption of the phage, it was centrifuged at $6000 \times \mathrm{g}$ for $10 \mathrm{~min}$. The pellet containing infected cells was re-suspended in $50 \mathrm{~mL}$ of fresh TSB and incubated at $37^{\circ} \mathrm{C}$, with shaking at $220 \mathrm{rpm}$. Two sets of samples were collected every $5 \mathrm{~min}$ for $1 \mathrm{~h}$. To release intracellular phages and determine the eclipse period, $\mathrm{CHCl}_{3}$ was added to one of the samples. Subsequently, the titre of each sample was immediately assessed using the double-layer agar plate method, and the latent period, eclipse period, and burst size were analyzed. All the experiments were performed in triplicate.

\subsection{Receptor Analysis}

The nucleotide sequence of the putative receptor binding protein (RBP) of phage CSA13 was predicted by nucleotide BLAST [19] analysis with that of phage S13' and S24-1, which is annotated as ORF16 in each genome. The amino acid sequence of putative RBP of CSA13 was aligned with that of S13' and S24-1 by Clustal X (ver. 2.0.11) [20], and the coverage and identity were analyzed by GeneDoc (ver. 2.7.000) [21]. The potential receptor for CSA13 was predicted based on the receptors for $\mathrm{S}^{\prime} 3^{\prime}$ and S24-1 [22,23]. To verify the predicted receptor, S. aureus RN4220 [24] was used (Table 1). We obtained a RN4220 $\Delta$ tagO mutant, which lacks the peptidoglycan-anchored wall teichoic acid (WTA) [25], and its complemented strain, carrying the pRB474-tagO plasmid. This plasmid was constructed by sub-cloning the tagO gene into an Escherichia coli-S. aureus shuttle expression vector [26]. Afterwards, $10 \mu \mathrm{L}$ of ten-fold diluted phage CSA13 lysate $\left(10^{12}\right.$ to $\left.10^{5} \mathrm{PFU} / \mathrm{mL}\right)$ were spotted from top-left to bottom-right on soft agar (TSB containing $0.4 \%$ agar) starting with the highest titer, with the wild-type RN4220, $\mathrm{RN} 4220 \Delta \operatorname{tag} \mathrm{O}$ mutant, and the tagO-complemented strain.

\subsection{Biofilm Reduction Assay with Phage CSA13}

Biofilm reduction assays were performed based on a previous study with some modifications [27]. Two different S. aureus strains-namely, S. aureus Newman and S. aureus CCARM 3793, incubated in TSB supplemented with $0.25 \% \mathrm{D}-(+)$-glucose (TSBg) were prepared. After cultures were grown, 1:100 dilutions were performed by adding $2 \mu \mathrm{L}$ of a pure cell suspension to $198 \mu \mathrm{L}$ of TSBg in each well of a 96-well polystyrene plate, while $200 \mu \mathrm{L}$ of TSBg was added as a negative control. After incubating the microplate for $24 \mathrm{~h}$ at $37^{\circ} \mathrm{C}$, all wells were washed three times with phosphate buffered saline (PBS). Once the biofilms were washed, they were treated with either $200 \mu \mathrm{L}$ of phage lysate $\left(10^{9}-10^{11} \mathrm{PFU} / \mathrm{mL}\right)$ in SM buffer (50 mM Tris-HCl, $\left.\mathrm{pH} 7.5,100 \mathrm{mM} \mathrm{NaCl}, 8 \mathrm{mM} \mathrm{MgSO}{ }_{4} \cdot 7 \mathrm{H}_{2} \mathrm{O}\right)$ or a buffer-only negative control. After statically incubating at $37^{\circ} \mathrm{C}$ for $24 \mathrm{~h}$, phage lysate was removed, and each well was washed once with PBS and stained with $1 \%$ crystal violet. Additional washing 
with PBS was done, followed by solubilization with $33 \%$ acetic acid. The absorbance of the obtained solution was measured at $570 \mathrm{~nm}$, and the sessile biomass was presented as an $A_{570}$ value.

\subsection{Bacteriophage Genomic DNA Purification}

Bacteriophage genomic DNA was purified as previously described [28]. Prior to purification, the phage lysates were treated with DNase and RNaseA at $37^{\circ} \mathrm{C}$ for $1 \mathrm{~h}$ to remove bacterial nucleic acid contaminants. The phage lysates were then treated with lysis buffer containing 0.5 M EDTA, $10 \mathrm{mg} / \mathrm{mL}$ proteinase $\mathrm{K}$, and $1 \%$ sodium dodecyl sulfate (SDS) for $1 \mathrm{~h}$ at $56^{\circ} \mathrm{C}$. Finally, an ethanol precipitation was performed, followed by a phenol-chloroform DNA extraction.

\subsection{Full-Genome Sequencing of Phage CSA13 and Bioinformatics Analysis}

Purified CSA13 phage genomic DNA was sequenced using a Genome Sequencer FLX titanium system (Roche, Mannheim, Germany) and assembled with the GS de novo assembler software (Roche) at Sanigen Inc., South Korea. Open reading frames (ORFs) were predicted using the FGENESB (http:/ / www.softberry.com), Glimmer v3.02 [29] and GeneMarkS [30] software packages. The ORFs were annotated using the InterProScan [31] and BLASTP [32] programs. Sequence alignments of CSA13 and staphylococcal phages from the Podoviridae, Myoviridae, and Siphoviridae families were performed by ClustalW [33], using whole-genome DNA sequences. Complete genome sequences of each taxon were acquired from the NCBI (www.ncbi.nlm.nih.gov) database. Sequence relationships were inferred using the neighbor-joining method [34], and the phylogenetic tree was constructed using MEGA7.0.21 [35]. The bootstrap value derived from 5000 replicates was considered to represent the evolutionary history of the analyzed taxa [36]. The evolutionary distances were computed using the p-distance method [37]. Comparative genome analyses of CSA13 and other Podoviridae phages were conducted by progressiveMauve [38,39] and ACT (Artemis Comparison Tool) [40]. Complete genome sequences of 16 staphylococcal Podoviridae phages were retrieved from the NCBI database: SAP-2, EU136189; BP39, KM366100; S13' , AB626963; S24-1, AB626962; SLPW, KU992911; SCH1, KY000084; SCH111, KY000085; 44AHJD, AF513032; P68, AF513033; 66, AY954949; PSa3, HF937074; GRCS, KJ210330; vB_SauP_phiAGO1.3, MG766218; vB_SauP_phiAGO1.9, MG766219; Andhra, KY442063; St 134, KY471386. The minimum score cut-off value of ACT analysis was 20. The complete genome sequence of $S$. aureus phage CSA13 was deposited in GenBank under the accession number MH107118.

\section{Results and Discussion}

\subsection{Isolation and Physiological Characteristics of S. aureus Phage CSA13}

The $S$. aureus-infecting phage CSA13 was newly isolated from a chicken. This phage formed clear plaques with a halo against the $S$. aureus clinical isolate FMB-1 as a bacterial host strain.

According to a previous study, the vast majority of known $S$. aureus phages belong to the Siphoviridae family [12], and only a small number, including phage SAP-2, belong to the Podoviridae family [41]. Transmission electron microscopy (TEM) revealed that phage CSA13 possesses a $40 \mathrm{~nm}$ icosahedral head with a short, non-contractile tail (Figure 1A). These results indicate that phage CSA13 is a member of the Podoviridae family, serogroup C, which features short-tailed viral particles. To determine the eclipse period, latent period, and burst size of phage CSA13, a one-step growth curve analysis was conducted with the host strain (Figure 1B). It was determined that the eclipse and latent periods were $15 \mathrm{~min}$ and $20 \mathrm{~min}$, respectively. The burst size was about $230 \mathrm{PFU} /$ infected cell, which is relatively higher than other prominent $S$. aureus phages. For example, among the Myoviridae family, phage K shows an average burst size of $60 \mathrm{PFU} /$ infected cell [15] and phage Stau2 shows a burst size of approximately $100 \mathrm{PFU} /$ infected cell [42]. These results indicated that phage CSA13 exhibits a high rate of phage production. 
A

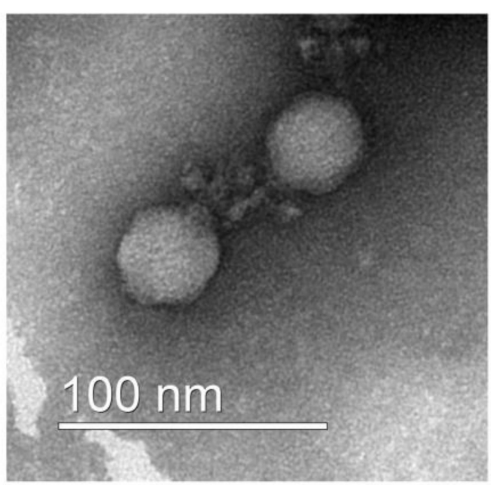

B

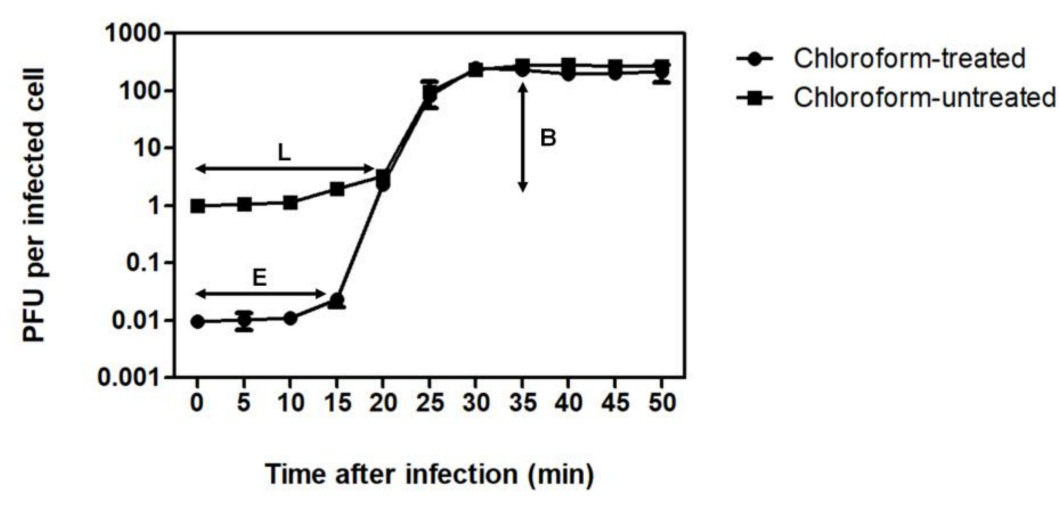

C

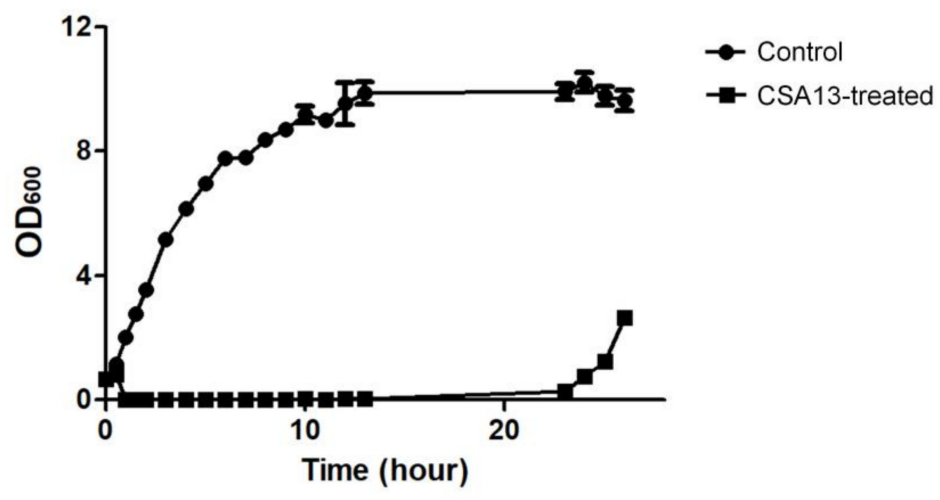

Figure 1. General characterizations of phage CSA13. (A) Electron micrograph of phage CSA13, which belongs to the Podoviridae family. The scale bar represents $100 \mathrm{~nm}$. (B) One-step growth curve analysis of phage CSA13 on an exponential culture of $S$. aureus clinical isolate FMB-1 incubated in tryptic soy broth (TSB) medium at $37^{\circ} \mathrm{C}$, with shaking at $220 \mathrm{rpm}$. The culture of S. aureus clinical isolate FMB-1 was divided into two groups; chloroform-treated $(\bullet)$ or untreated $(\boldsymbol{\square})$. E, eclipse period; L, latent period; B, burst size. (C) Inhibition assays of S. aureus clinical isolate FMB-1 with phage CSA13 at 37 ${ }^{\circ} \mathrm{C}$, with shaking at $220 \mathrm{rpm}$. Cells were prepared in two groups: control group without phage $(\bullet)$ or experimental group with phage CSA13, at an MOI of $1(\mathbf{\square})$. The data shown are the mean values from three independent measurements, and the error bars represent the standard deviations.

To determine the inhibition activity of phage CSA13, bacterial growth inhibition assays were performed (Figure $1 C$ ). The growth inhibition of S. aureus persisted for up to $23 \mathrm{~h}$ after infection with an MOI of 1.0, which is a stronger inhibitory effect than most other $S$. aureus phages, such as CS1 and DW2 [43], which show only $3 \mathrm{~h}$ of growth inhibition, or phage SA97, which showed up to $10 \mathrm{~h}$ inhibition with an MOI of 1.0 [44]. The above results demonstrate that phage CSA13 has a high 
replication rate and a strong inhibitory effect, which are essential properties for a phage to be used in phage therapy.

\subsection{Receptor Analysis of Phage CSA13}

It is known that peptidoglycan-anchored wall teichoic acids (WTA) of S. aureus serve as receptors for phage. For most cases, $S$. aureus synthesizes polyribitol phosphate WTA with substitutions such as $\alpha$-O-N-acetylglucosamine ( $\alpha$-O-GlcNAc), $\beta$-O- $N$-acetylglucosamine ( $\beta$-O-GlcNAc), or D-alanine [45]. In a previous study, it has been suggested that specific glycosylation pattern of WTA can prevent infection by Podoviridae [46]. For instance, S. aureus Podoviridae phage S13' and S24-1 have been revealed to exhibit different binding capacity to WTAs harboring different glycosidic patterns. The putative receptor-binding protein (RBP) of S13' requires $\beta-\mathrm{O}-\mathrm{GlcNAc}$ for binding, while that of S24-1 can bind regardless of glycosidic bonds, which makes WTA itself the receptor for S24-1 [22,23]. BLAST analysis of the CSA13 genome revealed a gene-encoding putative RBP of CSA13, and its amino acid sequence was compared with that of S13' and S24-1 (Figure S1). Putative RBP of CSA13 and S24-1 showed high sequence coverage (95\%) and identity (97\%), implying that CSA13 would recognize WTA as the receptor. Contrastingly, both RBP showed relatively low similarity to RBP of S13': CSA13, 67\% coverage, 79\% identity; S24-1, 69\% coverage, 80\% identity. In accordance with the assumption, the $\Delta$ tagO mutant of S. aureus (RN4220 $\Delta$ tagO) [47], which lacks WTA, was resistant to CSA13 (Figure 2B), and susceptibility to the phage was recovered by complementing the strain with the $\operatorname{tag} O$ gene (Figure 2C) [48].

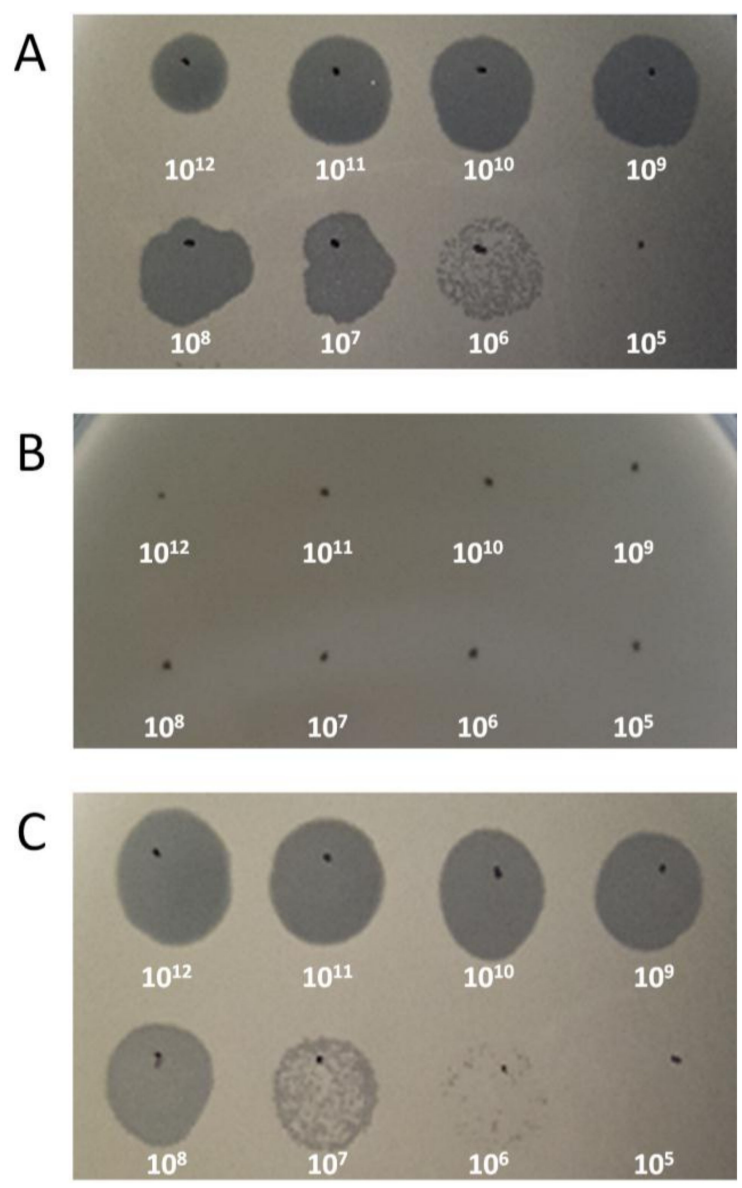

Figure 2. Wall teichoic acid (WTA)-dependent infection of $S$. aureus phage CSA13. (A) Phage CSA13 lysate was spotted onto lawns of wild-type RN4220, (B) $\Delta$ tagO mutant, and (C) tagO-complemented strains. Each number indicates the titer $(\mathrm{PFU} / \mathrm{mL})$ of phage CSA13 spotted on the plate. Plaque formation indicates successful adsorption and infection by phage CSA13. 


\subsection{Host Range of Phage CSA13}

To determine the antimicrobial spectrum of phage CSA13, 28 strains of S. aureus, including 15 laboratory isolates, and eight additional Gram-positive strains were used, as shown in Table 1. The results indicate that CSA13 selectively infected S. aureus strains; 11 out of 13 S. aureus-type strains, including MRSA strains, and all 15 S. aureus local isolates were infected by CSA13. In addition, phage CSA13 could infect three other staphylococcal strains other than S. aureus, including S. epidermis, S. hominis, and S. warneri. The wide antimicrobial spectrum of phage CSA13 suggests its potential applicability as a biocontrol agent in clinical settings.

Table 1. The antimicrobial spectrum of phage CSA13.

\begin{tabular}{|c|c|c|}
\hline Bacterial Host & Lytic Activity $^{a}$ & Origin \\
\hline \multicolumn{3}{|l|}{ Staphylococcal strains } \\
\hline S. aureus RN4220 & $\mathrm{T}$ & Laboratory strain \\
\hline S. aureus Newman & $\mathrm{I}$ & Human \\
\hline S. aureus ATCC 13301 & C & $\mathrm{N} / \mathrm{A}$ \\
\hline S. aureus ATCC 23235 & $\mathrm{~T}$ & Food \\
\hline S. aureus ATCC 33586 & $\mathrm{~T}$ & Human \\
\hline S. aureus ATCC 33593 & $\mathrm{C}$ & Human \\
\hline S. aureus KCTC 1916 & $\mathrm{C}$ & Human \\
\hline S. aureus ATCC 6538 & $\mathrm{C}$ & Human \\
\hline S. aureus ATCC 29213 & $\mathrm{C}$ & Human \\
\hline S. aureus ATCC 12600 & $\mathrm{~T}$ & Human \\
\hline MRSA CCARM 3793 & $\mathrm{C}$ & Human \\
\hline MRSA CCARM 3089 & C & Human \\
\hline MRSA CCARM 3090 & $\mathrm{I}$ & Human \\
\hline S. haemolyticus ATCC 29970 & I & Human \\
\hline S. epidermidis ATCC 35983 & $\mathrm{C}$ & Human \\
\hline S. hominis ATCC 27844 & $\mathrm{C}$ & Human \\
\hline S. warneri ATCC 10209 & $\mathrm{~T}$ & Antibiosis indicator for snake venoms \\
\hline \multicolumn{3}{|l|}{ Other Gram-positive bacteria } \\
\hline Enterococcus faecalis ATCC 29212 & - & Human \\
\hline Bacillus cereus ATCC 14579 & - & Farmhouse \\
\hline Bacillus subtilis ATCC 23857 & - & $\mathrm{N} / \mathrm{A}$ \\
\hline Listeria monocytogenes ATCC 19114 & - & Animal \\
\hline \multicolumn{3}{|l|}{ Laboratory isolates (S. aureus) } \\
\hline 129 & $\mathrm{C}$ & Animal \\
\hline 130 & $\mathrm{~T}$ & Animal \\
\hline 131 & $\mathrm{~T}$ & Animal \\
\hline 134 & $\mathrm{C}$ & Animal \\
\hline Clinical isolate 0055 & $\mathrm{C}$ & Human \\
\hline Clinical isolate 0136 & $\mathrm{C}$ & Human \\
\hline Clinical isolate 0154 & $\mathrm{~T}$ & Human \\
\hline Clinical isolate 0212 & $\mathrm{~T}$ & Human \\
\hline Clinical isolate 0600 & $\mathrm{C}$ & Human \\
\hline Clinical isolate-FMB_1 & $\mathrm{C}$ & Cotton from hospital \\
\hline 77 & $\mathrm{~T}$ & Human \\
\hline 79 & $\mathrm{~T}$ & Human \\
\hline 80 & $\mathrm{C}$ & Human \\
\hline 81 & $\mathrm{~T}$ & Human \\
\hline 82 & $\mathrm{~T}$ & Human \\
\hline
\end{tabular}

${ }^{a} \mathrm{C}$, clear plaque; T, turbid plaque; I, inhibition zone; -, no lytic effect. 


\subsection{Biofilm Reduction Efficacy of Phage CSA13}

The efficacy of phage CSA13 in reducing staphylococcal biofilm was examined by visual comparison based on the crystal violet staining method (Figure 3). In a 96-well polystyrene microplate, both S. aureus CCARM 3793 (MRSA) and Newman (MSSA) strains successfully formed biofilm in the presence of supplemented glucose. Biofilms formed by both S. aureus CCARM 3793 (Figure 3A) and S. aureus Newman (Figure 3B) were successfully removed by phage CSA13 in a PFU-dependent manner. Biofilm masses of S. aureus CCARM 3793 and S. aureus Newman were decreased by $86.5 \%$ and $56 \%$, respectively, after a $24 \mathrm{~h}$ treatment with $10^{9} \mathrm{PFU} / \mathrm{mL}$ of CSA13. When the dosage was increased to $10^{11} \mathrm{PFU} / \mathrm{mL}$, the biofilms were eradicated by $93.4 \%$ for CCARM 3793 and $78.5 \%$ for Newman, while the $S$. aureus CCARM 3793 strain displayed an approximately $40 \%$ stronger biofilm-forming capacity than S. aureus Newman. Considering that the antibiotic resistance of MRSA sacrifices virulence in exchange for an altered biofilm phenotype and elongated persistence $[49,50]$, the significant biofilm reduction efficacy of CSA13 against S. aureus CCARM 3793 emphasizes its potential as an anti-biofilm candidate in clinical environments, which are vulnerable to colonization by the biofilm of MRSA strains [49-51].

A

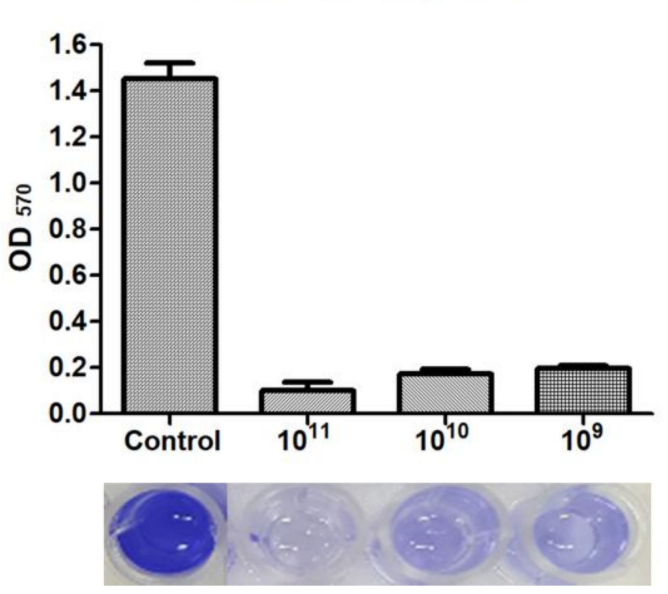

B

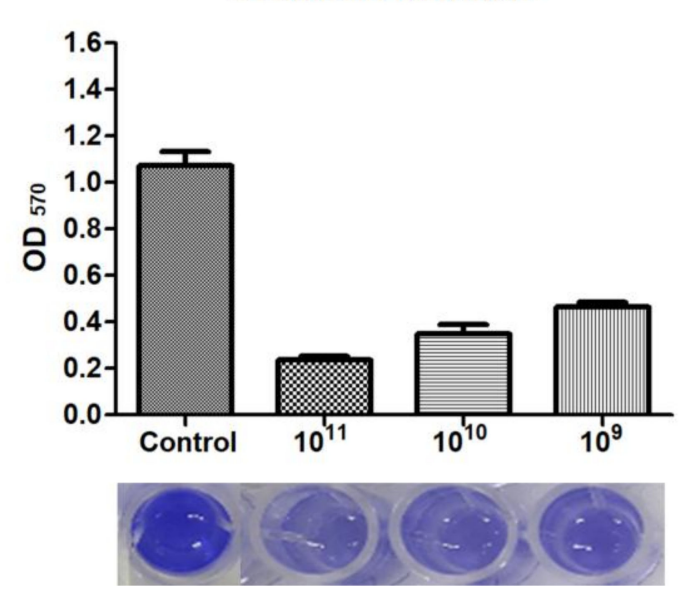

Figure 3. Removal of 24 h-old biofilm grown on a 96-well polystyrene microplate with phage CSA13. Biofilms of S. aureus CCARM 3793 (A) and Newman (B) were treated with three different PFUs of CSA13 for $24 \mathrm{~h}$. Each column represents the mean of triplicate experiments, and error bars indicate the standard deviation.

Besides phage CSA13, several other S. aureus phages have also been tested for their anti-biofilm activity $[5,52,53]$. However, those previously studied S. aureus phages were not as effective as CSA13 at degrading staphylococcal biofilms. These results suggest that the anti-biofilm activity of phage CSA13 would be useful for the development of powerful biocontrol agents against both methicillin-susceptible and -resistant $S$. aureus strains.

\subsection{Genome Analysis of Phage CSA13}

Genomic features of phage CSA13 were revealed by whole genome sequencing. CSA13 is a double-stranded DNA (dsDNA) virus with a 17,034-base-pair-long linear chromosome harboring $234 \mathrm{bp}$-long inverted terminal repeat sequences at both ends. The average $\mathrm{G}+\mathrm{C}$ content of the genome is $28.97 \%$, and it contains 18 open reading frames (ORFs), but no tRNAs were predicted (Figure 4). Taken together with morphological traits, such genomic properties suggest that phage CSA13 is a member of the Picovirinae subfamily [54]. According to the clusters of the orthologous groups (COG) database, the ORFs were categorized into four functional groups: structural (major capsid protein, collar protein, tail fiber), lysis ( $\mathrm{N}$-acetylmuramoyl-L-alanine amidase, holin), DNA 
manipulation (DNA polymerase, ssDNA binding protein), and DNA packaging. Detailed information of predicted ORFs are specified in Table S1. Among the ORFs, two were predicted to exert lytic activity against the host. N-acetylmuramoyl-L-alanine amidase (phCSA13_007) is reported as one of five types of endolysin [55], which contribute to the hydrolysis of bacterial peptidoglycan. Endolysin is generally composed of two polypeptide domains: enzymatically active domains (EADs) at the $\mathrm{N}$-terminal position, and cell wall binding domains (CBDs) at the C-terminal position [56]. The EAD and CBD of the predicted endolysin (phCSA13_007) were classified into cysteine, histidine-dependent amidohydrolases/peptidase (CHAP) (pfam05257), an amidase, and a SH3_5 (pfam08460) domain by BLASTP analysis [32]. On the chromosome, phCSA13_007 is located in between ORFs coding structural proteins, which is a distinctive feature of P68-like viruses [54].

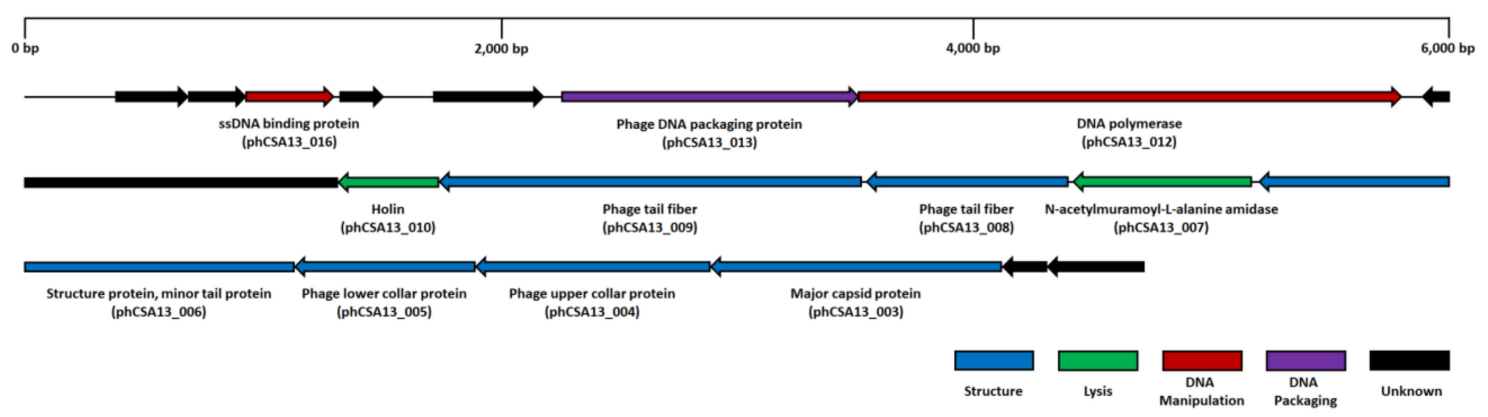

Figure 4. Genome map of phage CSA13. The arrangement of predicted ORFs on the CSA13 genome. Functional groups are categorized into colors.

\subsection{Comparative Genome Analysis of Phage CSA13}

In general, phylogenetic analysis of microbial entities relies on ribosomal RNA sequences [57]. In terms of bacteriophages, the absence of ribosomal sequence makes it difficult to classify them and measure their biodiversity. In previous studies, it was revealed that some phage proteins, such as terminase large subunits, are more conserved than others, implying that they could have a potential role as phylogenetic markers [58]. Despite the fact that some structural proteins were utilized as a basis to study phage phylogeny [59-61], due to their highly diverse nature, such genes could not serve as a universal marker for the biodiversity of phages. In fact, the coding genes for terminase are not predicted to be present in the genome of phage CSA13 and other Podoviridae phages. Hence, in this research, whole-genome sequencing of phage CSA13 and other S. aureus Podoviridae phages were analyzed together with S. aureus Myoviridae and Siphoviridae phage genomes (Figure 5). All of the Podoviridae phages are categorized into the Picovirinae subfamily, which has several unique features; those features include a small genome and similar numbers of genes. There are two genera in the Picovirinae, and Staphylococcus phages belong to the genus "P68virus" [54]. From the resulting tree, Podoviridae phages could be differentiated from other families, while a majority of Podoviridae phages were closely related to one another. Phage SAP-2 turned out to have the highest similarity to phage CSA13, even though most Podoviridae phages were not as diverse as those in the Myoviridae or Siphoviridae families. 


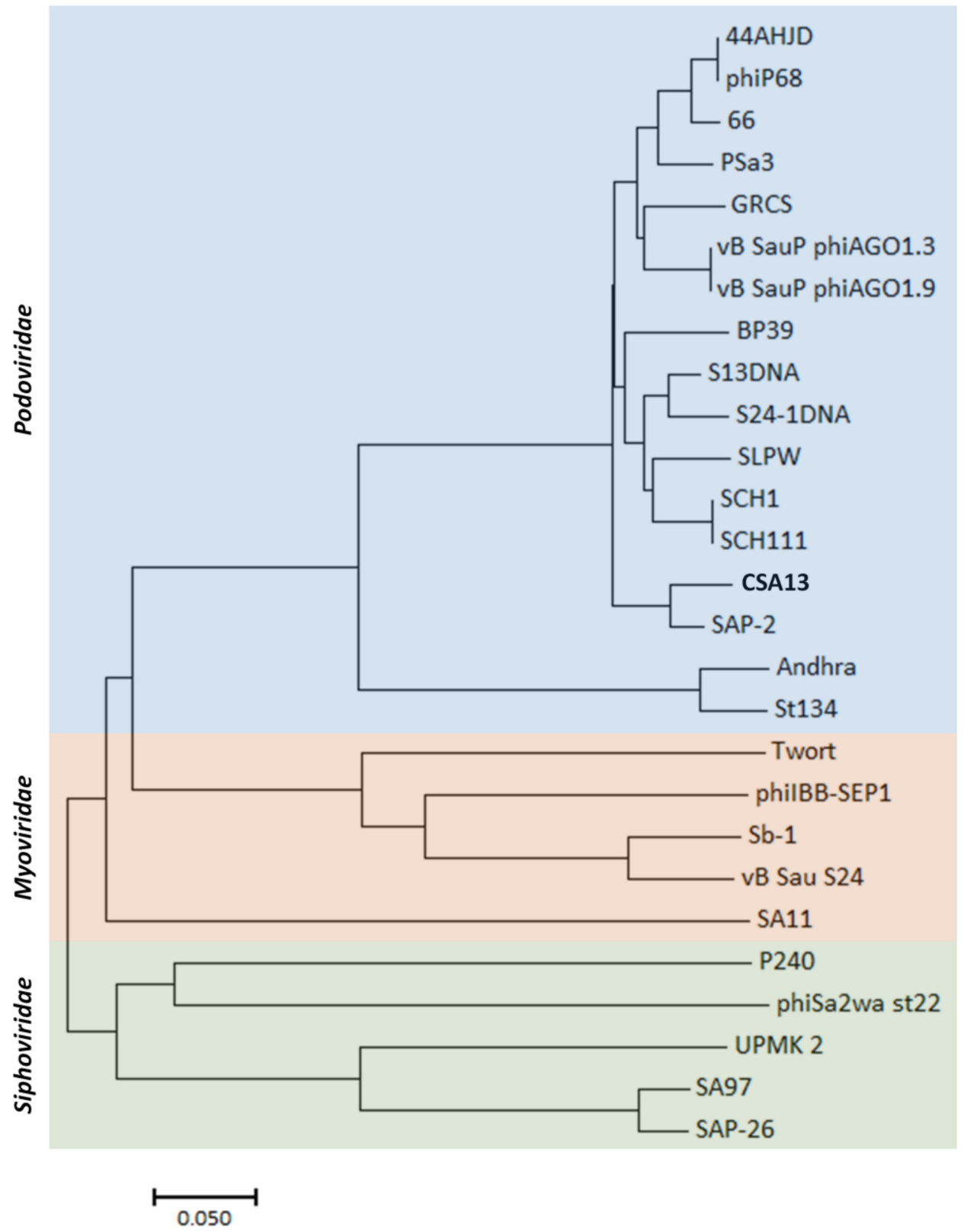

Figure 5. Phylogenetic tree of staphylococcal phages. Whole-genome sequences were aligned using ClustalW. The tree was constructed with neighbor-joining method, and the evolutionary distances were computed with the p-distance method by MEGA7 software.

The relatively homologous nature of staphylococcal Podoviridae phages could also be observed from their genome structure (Figure 6). Due to their small genome $(<20 \mathrm{kbp})$, there are less than 30 ORFs predicted on the genome of staphylococcal Podoviridae phages. Their linear genomes share a highly conserved structure and some very unique features, as described in a previous report [54]. The classical lysis cassette of lambdoid phages, which is composed of the lysin and holin genes [62,63], was not identified. Instead, endolysin, primarily amidases, appeared in between morphogenesis genes on the chromosome. In addition, among the structural genes, the gene encoding the capsid protein resided at the right end of the genome. 


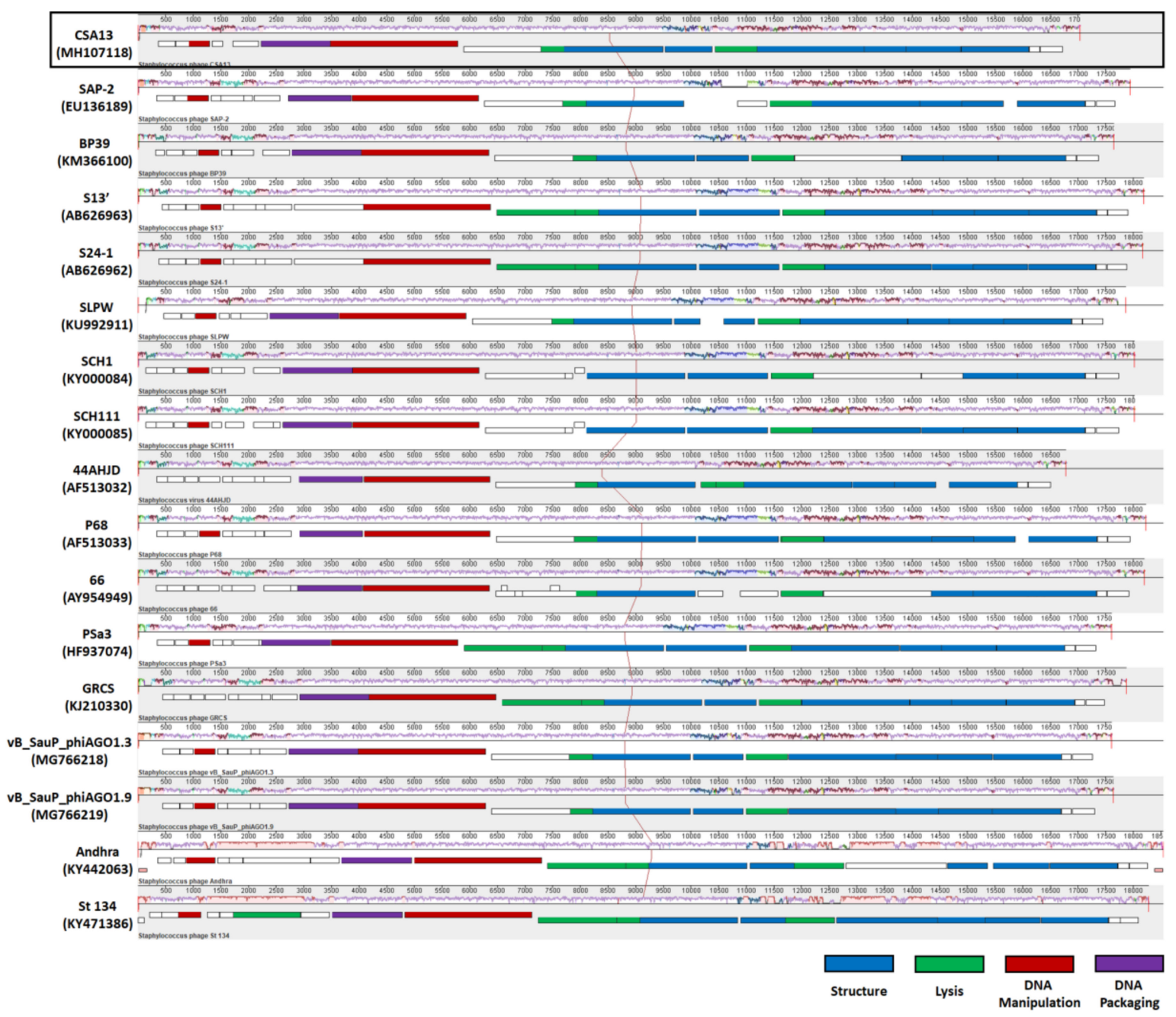

Figure 6. Multiple alignment of staphylococcal Podoviridae phage genomes by progressiveMauve. A total of 17 complete genomes were aligned; the genomes of phage CSA13 and phage 66 were annotated in an opposite direction to others; thus, the reverse complementary sequence was used. The GenBank accession number of each sequence is indicated. COG assignments for each ORF are represented in different colors, while the ORFs with unknown functions are depicted as blank boxes.

Despite a few variations, the overall similarity in genome structure could well explain the low diversity represented in the phylogeny.

In comparison with the closest phage SAP-2, phage CSA13 exhibited strong sequence similarity (97\% coverage with $97 \%$ identity) throughout the genome. As revealed in the ACT data, phCSA13_006, which was predicted to encode the "structure protein, minor tail protein", displayed the most apparent difference when compared with phage SAP-2 (Figure 7). Low sequence similarity (68\% coverage with 79\% identity) between phCSA13_006 and ORF15 of SAP-2 was verified by amino acid sequence alignment analysis (Figure S1). Since phCSA13_006 is expected to serve as the receptor binding protein, a certain level of difference in amino acid sequence may contribute to a distinct host spectrum. The fact that ORF15 of SAP-2 was highly similar to ORF16 of S13', which is unable to bind WTA-lacking $\beta$-O-GlcNAc, implies that the host range of SAP-2 is narrower than CSA13 [41]. In terms of amidase, the amino acid sequence comparison resulted in $88 \%$ identity with a coverage of $92 \%$ (Figure S2). Minor sequence diversity was observed in the CBD domain, which may also affect the variant host range between two species [64]. Examination of the properties of each amidase, for instance, the lysis activity or host spectrum, would be required for further research to build synergistic phage-mediated biocontrol strategies. 


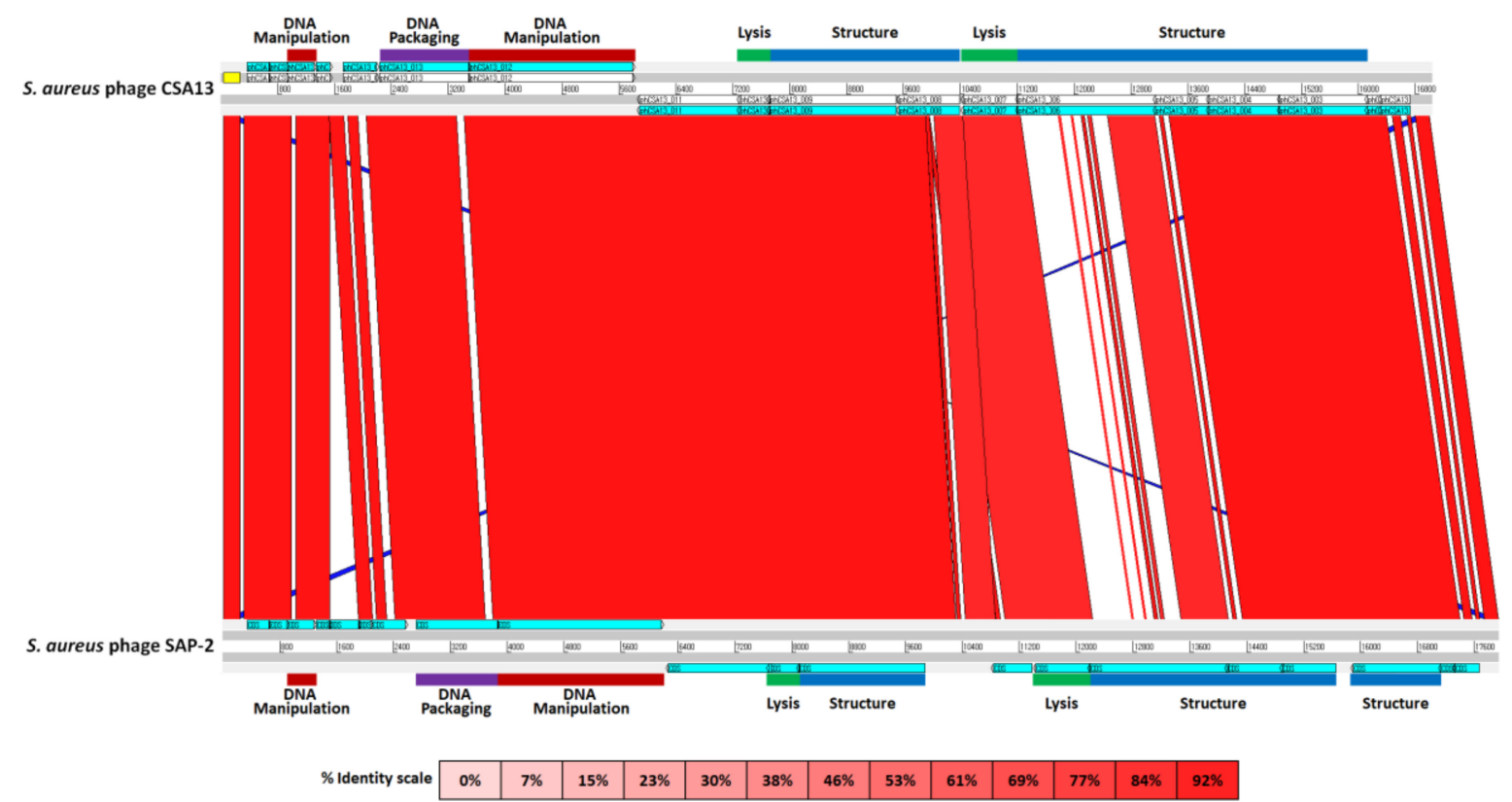

Figure 7. Comparative analysis of phage CSA13 and phage SAP-2 genomes by ACT. ORFs were designated with COG categories and corresponding color labels. The genome of phage CSA13 was annotated in an opposite direction; thus, the reverse complementary sequence was used. The color intensity of each band is proportional to the percent identity.

\section{Conclusions}

An integrated study upon newly discovered phage CSA13 revealed its physiological and genetic characteristics. Its inhibitory activity against bacterial hosts during interactions under various conditions, especially when host bacteria were developing biofilm, suggests that the phage itself can potentially serve as an effective biocontrol agent. Exploration of the genome uncovered its significantly conserved structure as a member of the staphylococcal Podoviridae. Despite the general similarity, phage CSA13 was distinguished from other Podoviridae phages, and further research would allow for insight into how such differences led to divergent phenotypes.

Supplementary Materials: Supplementary materials can be found at http:/ / www.mdpi.com/1999-4915/11/1/ $54 /$ s1.

Author Contributions: Y.C. carried out all the experiments, characterization of the morphology and physiology, as well as preparation and analysis of the genome. Y.C. took part in drafting the manuscript. J.C. carried out the genome and comparative genome analysis and participated in drafting the manuscript. Y.C. and J.C. have contributed equally to the study. B.S. participated in organizing experimental designs and experiments. S.R. conceived the study, participated in the design, and wrote the manuscript. All authors read and approved the final manuscript.

Funding: This work was supported by Basic Science Research Programs (NRF-2017R1A2A1A17069378) through the National Research Foundation of Korea (NRF) funded by the Ministry of Science, ICT and Future Planning and Korea Institute of Planning and Evaluation for Technology in Food, Agriculture, Forestry (IPET) through High Value-added Food Technology Development Program, funded by Ministry of Agriculture, Food and Rural Affairs (MAFRA)(117064-03-1-HD050). Y.C. and J.C. were supported by the BK21 Plus Program of Department of Agricultural Biotechnology, Seoul National University, Seoul, Korea.

Conflicts of Interest: The authors declare no conflict of interest.

\section{References}

1. Lowy, F.D. Staphylococcus aureus infections. N. Engl. J. Med. 1998, 339, 520-532. [CrossRef] [PubMed]

2. Moormeier, D.E.; Bayles, K.W. Staphylococcus aureus biofilm: A complex developmental organism. Mol. Microbiol. 2017, 104, 365-376. [CrossRef] [PubMed] 
3. Miao, J.; Liang, Y.; Chen, L.; Wang, W.; Wang, J.; Li, B.; Li, L.; Chen, D.; Xu, Z. Formation and development of staphylococcus biofilm: With focus on food safety. J. Food Saf. 2017, 37, e12358. [CrossRef]

4. Li, X.-H.; Lee, J.-H. Antibiofilm agents: A new perspective for antimicrobial strategy. J. Microbiol. 2017, 55, 753-766. [CrossRef] [PubMed]

5. Gutiérrez, D.; Rodríguez-Rubio, L.; Martínez, B.; Rodríguez, A.; García, P. Bacteriophages as weapons against bacterial biofilms in the food industry. Front. Microbiol. 2016, 7, 825. [CrossRef] [PubMed]

6. Dubey, K.; Chandraker, S.; Sao, S.; Gupta, A.; Dubey, S.K. Bacteriophages as an antibacterial agent: A promising alternative. Int. J. Curr. Microbiol. Appl. Sci. 2016, 5, 231-234. [CrossRef]

7. Endersen, L.; O'Mahony, J.; Hill, C.; Ross, R.P.; McAuliffe, O.; Coffey, A. Phage therapy in the food industry. Annu. Rev. Food Sci. Technol. 2014, 5, 327-349. [CrossRef] [PubMed]

8. Hughes, K.A.; Sutherland, I.W.; Clark, J.; Jones, M.V. Bacteriophage and associated polysaccharide depolymerases-Novel tools for study of bacterial biofilms. J. Appl. Microbiol. 2002, 85, 583-590. [CrossRef]

9. Donlan, R.M. Preventing biofilms of clinically relevant organisms using bacteriophage. Trends Microbiol. 2009, 17, 66-72. [CrossRef] [PubMed]

10. Arciola, C.R.; Campoccia, D.; Ravaioli, S.; Montanaro, L. Polysaccharide intercellular adhesin in biofilm: Structural and regulatory aspects. Front. Cell. Infect. Microbiol. 2015, 5, 7. [CrossRef] [PubMed]

11. Bárdy, P.; Pantůček, R.; Benešík, M.; Doškař, J. Genetically modified bacteriophages in applied microbiology. J. Appl. Microbiol. 2016, 121, 618-633. [CrossRef] [PubMed]

12. Deghorain, M.; Van Melderen, L. The staphylococci phages family: An overview. Viruses 2012, 4, $3316-3335$. [CrossRef]

13. Rohwer, F.; Edwards, R. The phage proteomic tree: A genome-based taxonomy for phage. J. Bacteriol. 2002, 184, 4529-4535. [CrossRef] [PubMed]

14. Glazko, G.; Makarenkov, V.; Liu, J.; Mushegian, A. Evolutionary history of bacteriophages with double-stranded DNA genomes. Biol. Direct 2007, 2, 36. [CrossRef] [PubMed]

15. Chang, Y.; Lee, J.-H.; Shin, H.; Heu, S.; Ryu, S. Characterization and complete genome sequence analysis of staphylococcus aureus bacteriophage sa12. Virus Genes 2013, 47, 389-393. [CrossRef] [PubMed]

16. Kwiatek, M.; Parasion, S.; Mizak, L.; Gryko, R.; Bartoszcze, M.; Kocik, J. Characterization of a bacteriophage, isolated from a cow with mastitis, that is lytic against staphylococcus aureus strains. Arch. Virol. 2012, 157, 225-234. [CrossRef]

17. Park, M.; Lee, J.H.; Shin, H.; Kim, M.; Choi, J.; Kang, D.H.; Heu, S.; Ryu, S. Characterization and comparative genomic analysis of a novel bacteriophage, sfp10, simultaneously inhibiting both salmonella enterica and Escherichia coli o157:H7. Appl. Environ. Microbiol. 2012, 78, 58-69. [CrossRef]

18. Lu, Z.; Breidt, F.; Fleming, H.P.; Altermann, E.; Klaenhammer, T.R. Isolation and characterization of a lactobacillus plantarum bacteriophage, $\varphi \mathrm{jl}-1$, from a cucumber fermentation. Int. J. Food Microbiol. 2003, 84, 225-235. [CrossRef]

19. Altschul, S.F.; Gish, W.; Miller, W.; Myers, E.W.; Lipman, D.J. Basic local alignment search tool. J. Mol. Biol. 1990, 215, 403-410. [CrossRef]

20. Larkin, M.A.; Blackshields, G.; Brown, N.P.; Chenna, R.; McGettigan, P.A.; McWilliam, H.; Valentin, F.; Wallace, I.M.; Wilm, A.; Lopez, R.; et al. Clustal w and clustal x version 2.0. Bioinformatics 2007, 23, 2947-2948. [CrossRef]

21. Nicholas, K.B.; Nicholas, H.B.J.; Deerfield, D.W. GeneDoc: Analysis and visualization of genetic variation. Embnew. News 1997, 4, 14.

22. Uchiyama, J.; Takemura-Uchiyama, I.; Kato, S.-I.; Sato, M.; Ujihara, T.; Matsui, H.; Hanaki, H.; Daibata, M.; Matsuzaki, S. In silico analysis of ahjd-like viruses, staphylococcus aureus phages s24-1 and s13', and study of phage s24-1 adsorption. MicrobiologyOpen 2014, 3, 257-270. [CrossRef] [PubMed]

23. Uchiyama, J.; Taniguchi, M.; Kurokawa, K.; Takemura-Uchiyama, I.; Ujihara, T.; Shimakura, H.; Sakaguchi, Y.; Murakami, H.; Sakaguchi, M.; Matsuzaki, S. Adsorption of staphylococcus viruses s13' and s24-1 on staphylococcus aureus strains with different glycosidic linkage patterns of wall teichoic acids. J. Gen. Virol. 2017, 98, 2171-2180. [CrossRef] [PubMed]

24. Wann, E.R.; Dassy, B.; Fournier, J.-M.; Foster, T.J. Genetic analysis of the cap5 locus of staphylococcus aureus. FEMS Microbiol. Lett. 2006, 170, 97-103. [CrossRef] [PubMed]

25. Swoboda, J.G.; Campbell, J.; Meredith, T.C.; Walker, S. Wall teichoic acid function, biosynthesis, and inhibition. Chembiochem 2010, 11, 35-45. [CrossRef] [PubMed] 
26. Brückner, R. A series of shuttle vectors for bacillus subtilis and Escherichia coli. Gene 1992, 122, 187-192. [CrossRef]

27. Kelly, D.; McAuliffe, O.; Ross, R.P.; Coffey, A. Prevention of Staphylococcus aureus biofilm formation and reduction in established biofilm density using a combination of phage $\mathrm{k}$ and modified derivatives. Lett. Appl. Microbiol. 2012, 54, 286-291. [CrossRef]

28. Wilcox, S.A.; Toder, R.; Foster, J.W. Rapid isolation of recombinant lambda phage DNA for use in fluorescence in situ hybridization. Chromosome Res. 1996, 4, 397-404. [CrossRef]

29. Delcher, A.L.; Bratke, K.A.; Powers, E.C.; Salzberg, S.L. Identifying bacterial genes and endosymbiont DNA with glimmer. Bioinformatics 2007, 23, 673-679. [CrossRef]

30. Besemer, J.; Lomsadze, A.; Borodovsky, M. Genemarks: A self-training method for prediction of gene starts in microbial genomes. Implications for finding sequence motifs in regulatory regions. Nucleic Acids Res. 2001, 29, 2607-2618. [CrossRef]

31. Žiedaitè, G.; Daugelavičius, R.; Bamford, J.K.H.; Bamford, D.H. The holin protein of bacteriophage prd1 forms a pore for small-molecule and endolysin translocation. J. Bacteriol. 2005, 187, 5397-5405. [CrossRef] [PubMed]

32. Altschul, S.F.; Madden, T.L.; Schäffer, A.A.; Zhang, J.; Zhang, Z.; Miller, W.; Lipman, D.J. Gapped blast and psi-blast: A new generation of protein database search programs. Nucleic Acids Res. 1997, 25, 3389-3402. [CrossRef]

33. Thompson, J.D.; Higgins, D.G.; Gibson, T.J. Clustal w: Improving the sensitivity of progressive multiple sequence alignment through sequence weighting, position-specific gap penalties and weight matrix choice. Nucleic Acids Res. 1994, 22, 4673-4680. [CrossRef] [PubMed]

34. Saitou, N.; Nei, M. The neighbor-joining method: A new method for reconstructing phylogenetic trees. Mol. Biol. Evol. 1987, 4, 406-425. [PubMed]

35. Kumar, S.; Stecher, G.; Tamura, K. Mega7: Molecular evolutionary genetics analysis version 7.0 for bigger datasets. Mol. Biol. Evol. 2016, 33, 1870-1874. [CrossRef] [PubMed]

36. Felsenstein, J. Confidence limits on phylogenies: An approach using the bootstrap. Evolution 1985, 39, 783-791. [CrossRef] [PubMed]

37. Nei, M.; Kumar, S. Molecular Evolution and Phylogenetics; Oxford University Press: Oxford, UK, 2000.

38. Darling, A.C.E.; Mau, B.; Blattner, F.R.; Perna, N.T. Mauve: Multiple alignment of conserved genomic sequence with rearrangements. Genome Res. 2004, 14, 1394-1403. [CrossRef] [PubMed]

39. Darling, A.E.; Mau, B.; Perna, N.T. Progressivemauve: Multiple genome alignment with gene gain, loss and rearrangement. PLoS ONE 2010, 5, e11147. [CrossRef] [PubMed]

40. Carver, T.J.; Rutherford, K.M.; Berriman, M.; Rajandream, M.-A.; Barrell, B.G.; Parkhill, J. Act: The artemis comparison tool. Bioinformatics 2005, 21, 3422-3423. [CrossRef] [PubMed]

41. Son, J.S.; Lee, S.J.; Jun, S.Y.; Yoon, S.J.; Kang, S.H.; Paik, H.R.; Kang, J.O.; Choi, Y.J. Antibacterial and biofilm removal activity of a podoviridae Staphylococcus aureus bacteriophage sap-2 and a derived recombinant cell-wall-degrading enzyme. Appl. Microbiol. Biotechnol. 2010, 86, 1439-1449. [CrossRef] [PubMed]

42. Hsieh, S.E.; Lo, H.H.; Chen, S.T.; Lee, M.C.; Tseng, Y.H. Wide host range and strong lytic activity of Staphylococcus aureus lytic phage stau2. Appl. Environ. Microbiol. 2011, 77, 756-761. [CrossRef]

43. O'Flaherty, S.; Ross, R.P.; Flynn, J.; Meaney, W.J.; Fitzgerald, G.F.; Coffey, A. Isolation and characterization of two anti-staphylococcal bacteriophages specific for pathogenic staphylococcus aureus associated with bovine infections. Lett. Appl. Microbiol. 2005, 41, 482-486. [CrossRef] [PubMed]

44. Chang, Y.; Shin, H.; Lee, J.-H.; Park, C.; Paik, S.-Y.; Ryu, S. Isolation and genome characterization of the virulent staphylococcus aureus bacteriophage sa97. Viruses 2015, 7, 5225-5242. [CrossRef] [PubMed]

45. Xia, G.; Corrigan, R.M.; Winstel, V.; Goerke, C.; Gründling, A.; Peschel, A. Wall teichoic acid-dependent adsorption of staphylococcal siphovirus and myovirus. J. Bacteriol. 2011, 193, 4006-4009. [CrossRef] [PubMed]

46. Li, X.; Gerlach, D.; Du, X.; Larsen, J.; Stegger, M.; Kühner, P.; Peschel, A.; Xia, G.; Winstel, V. An accessory wall teichoic acid glycosyltransferase protects staphylococcus aureus from the lytic activity of podoviridae. Sci. Rep. 2015, 5, 17219. [CrossRef] [PubMed]

47. Oku, Y.; Kurokawa, K.; Matsuo, M.; Yamada, S.; Lee, B.-L.; Sekimizu, K. Pleiotropic roles of polyglycerolphosphate synthase of lipoteichoic acid in growth of staphylococcus aureus cells. J. Bacteriol. 2009, 191, 141-151. [CrossRef] [PubMed] 
48. Park, K.H.; Kurokawa, K.; Zheng, L.; Jung, D.J.; Tateishi, K.; Jin, J.O.; Ha, N.C.; Kang, H.J.; Matsushita, M.; Kwak, J.Y.; et al. Human serum mannose-binding lectin senses wall teichoic acid glycopolymer of Staphylococcus aureus, which is restricted in infancy. J. Biol. Chem. 2010, 285, 27167-27175. [CrossRef] [PubMed]

49. Pozzi, C.; Waters, E.M.; Rudkin, J.K.; Schaeffer, C.R.; Lohan, A.J.; Tong, P.; Loftus, B.J.; Pier, G.B.; Fey, P.D.; Massey, R.C.; et al. Methicillin resistance alters the biofilm phenotype and attenuates virulence in Staphylococcus aureus device-associated infections. PLoS Pathog. 2012, 8, e1002626. [CrossRef]

50. McCarthy, H.; Rudkin, J.K.; Black, N.S.; Gallagher, L.; O'Neill, E.; O'Gara, J.P. Methicillin resistance and the biofilm phenotype in staphylococcus aureus. Front. Cell. Infect. Microbiol. 2015, 5, 1. [CrossRef]

51. O'Neill, E.; Pozzi, C.; Houston, P.; Smyth, D.; Humphreys, H.; Robinson, D.A.; O'Gara, J.P. Association between methicillin susceptibility and biofilm regulation in Staphylococcus aureus isolates from device-related infections. J. Clin. Microbiol. 2007, 45, 1379-1388. [CrossRef]

52. Vandersteegen, K.; Kropinski, A.M.; Nash, J.H.E.; Noben, J.-P.; Hermans, K.; Lavigne, R. Romulus and remus, two phage isolates representing a distinct clade within the twortlikevirus genus, display suitable properties for phage therapy applications. J. Virol. 2013, 87, 3237-3247. [CrossRef] [PubMed]

53. Rahman, M.; Kim, S.; Kim, S.M.; Seol, S.Y.; Kim, J. Characterization of induced Staphylococcus aureus bacteriophage sap-26 and its anti-biofilm activity with rifampicin. Biofouling 2011, 27, 1087-1093. [CrossRef] [PubMed]

54. Family-Podoviridae. In Virus Taxonomy; King, A.M.Q.; Adams, M.J.; Carstens, E.B.; Lefkowitz, E.J. (Eds.) Elsevier: San Diego, CA, USA, 2012; pp. 63-85.

55. Borysowski, J.; Weber-Dabrowska, B.; Górski, A. Bacteriophage endolysins as a novel class of antibacterial agents. Exp. Biol. Med. 2006, 231, 366-377. [CrossRef]

56. Loessner, M.J. Bacteriophage endolysins-Current state of research and applications. Curr. Opin. Microbiol. 2005, 8, 480-487. [CrossRef] [PubMed]

57. Lane, D.J.; Pace, B.; Olsen, G.J.; Stahl, D.A.; Sogin, M.L.; Pace, N.R. Rapid determination of 16s ribosomal RNA sequences for phylogenetic analyses. Proc. Natl. Acad. Sci. USA 1985, 82, 6955-6959. [CrossRef] [PubMed]

58. Casjens, S. Prophages and bacterial genomics: What have we learned so far? Mol. Microbiol. 2003, 49, $277-300$. [CrossRef] [PubMed]

59. Hambly, E.; Tétart, F.; Desplats, C.; Wilson, W.H.; Krisch, H.M.; Mann, N.H. A conserved genetic module that encodes the major virion components in both the coliphage $\mathrm{t} 4$ and the marine cyanophage S-PM2. Proc. Natl. Acad. Sci. USA 2001, 98, 11411-11416. [CrossRef] [PubMed]

60. Le Marrec, C.; van Sinderen, D.; Walsh, L.; Stanley, E.; Vlegels, E.; Moineau, S.; Heinze, P.; Fitzgerald, G.; Fayard, B. Two groups of bacteriophages infecting streptococcus thermophilus can be distinguished on the basis of mode of packaging and genetic determinants for major structural proteins. Appl. Environ. Microbiol. 1997, 63, 3246-3253.

61. Tétart, F.; Desplats, C.; Kutateladze, M.; Monod, C.; Ackermann, H.-W.; Krisch, H.M. Phylogeny of the major head and tail genes of the wide-ranging t4-type bacteriophages. J. Bacteriol. 2001, 183, 358-366. [CrossRef]

62. Catalão, M.J.; Gil, F.; Moniz-Pereira, J.; São-José, C.; Pimentel, M. Diversity in bacterial lysis systems: Bacteriophages show the way. FEMS Microbiol. Rev. 2012, 37, 554-571. [CrossRef]

63. Young, R. Bacteriophage lysis: Mechanism and regulation. Microbiol. Rev. 1992, 56, 430-481. [PubMed]

64. Becker, S.C.; Foster-Frey, J.; Stodola, A.J.; Anacker, D.; Donovan, D.M. Differentially conserved staphylococcal sh3b_5 cell wall binding domains confer increased staphylolytic and streptolytic activity to a streptococcal prophage endolysin domain. Gene 2009, 443, 32-41. [CrossRef] [PubMed]

(C) 2019 by the authors. Licensee MDPI, Basel, Switzerland. This article is an open access article distributed under the terms and conditions of the Creative Commons Attribution (CC BY) license (http:/ / creativecommons.org/licenses/by/4.0/). 